HABITAT, 31 (3), 2020, 115-124

DOI: 10.21776/ub.habitat.2020.031.3.14

\title{
A Study of the Potential of Ecotourism Development in Konawe Islands Regency, Southeast Sulawesi Province, Indonesia
}

\author{
Hidrawati $^{*}$, Normayasari ${ }^{2}$, Sariamin Sahari $^{3}$, Samsul Alam Fyka ${ }^{4}$ and Wa Ode Yusria ${ }^{5}$ \\ 1,4,5 Department of Agribusiness, Faculty of Agriculture, Halu Oleo University, Kendari, Southeast Sulawesi, \\ Indonesia \\ ${ }^{2}$ Department of Conservation, Maritime and Fisheries Community Academy, Wakatobi Regency, Southeast \\ Sulawesi, Indonesia \\ ${ }^{3}$ Department of Ecotourism, Maritime and Fisheries Community Academy, Wakatobi Regency, Southeast \\ Sulawesi, Indonesia
}

Received: 20 January 2020; Revised: 16 May 2020; Accepted: 20 September 2020

\begin{abstract}
The ecotourism potential development in Konawe Islands, Southeast Sulawesi Province requires academic study as a foothold in region policy making by all development stakeholders. This study aims to provide data and information about the potential of natural resources could be the ecotourism object, analyzing the perceptions of local communities, and formulating strategic plan for ecotourism development. The study was conducted from April-October 2019. This research used quantitative methods with data that were collected from observations, interviews, Focus Group Discussion (FGD) and literature studies. Data analysis was made using quality criteria scale of flora fauna diversity, SWOT analysis and litmus tests. The results of the study showed that Konawe Islands Regency has potential ecotourism objects in coastal-sea panoramas (Sawaea beach and Kampa beach), and in the mainland-hills with waterfalls panoramas (Tumburano waterfalls and Lanuku waterfalls). The results of importance/significance measurements indicate that the flora potential have a scale value of 3 (moderate), the fauna potential have scale of value 4 (good) and the potential criteria of "B", which indicates that the tourist attraction has a potential quality to be developed as ecotourism. Local people's perception is very positive because they believe there are economic, socio-cultural and ecological benefits from ecotourism development. The results of the SWOT analysis with the Litmus test found some main strategies in form program plans such as increasing the knowledge and skills tourism community, increasing the availability of capital financial for ecotourism businesses and development of ecotourism infrastructure facilities. Besides that, the main strategies from SWOT analysis result are promotion of ecotourism objects, the stipulation of rules about management of attractions; and deal with potential conflict issues and abrasion or erosion.
\end{abstract}

Key words: ecotourism; konawe islands; potential

\section{How to Cite:}

Sahari, S., Fyka, S. A., \& Yusria, W. O. (2020). A Study of the Potential of Ecotourism Development in Konawe Islands Regency, Southeast Sulawesi Province, Indonesia. HABITAT, 31(3), 115-124. https://doi.org/10.21776/ub.habitat.2020.031.3.14

\section{Introduction}

The Government of Konawe Islands Regency established tourism as one of the main development sectors in its region for several reasons. First, Konawe Islands Regency as a New Autonomous

*Correspondence Author.

E-mail: hidrawati@uho.ac.id
Region based on Law Number 13 of 2013 with the development branding "Hidden Pearls on Gift Island". The branding is confirms Konawe Islands as an area has the natural tourism potential to be developed (Mukhayar, Pasolon, \& Jaya, 2019). A number of tourism potentials will be the target of this study. Secondly, Ecotourism is a characterized tourism form by promoting conservation and environmental education (Blamey, 2001; Fennell,

Available online at HABITAT website: http://www.habitat.ub.ac.id

ISSN: 0853-5167 (p); 2338-2007 (e) 
2020) economic welfare of the population (Wood, 2002) and respect for local culture (Carrier \& Macleod, 2005; Chiu, Lee, \& Chen, 2014). These characteristics are in line with wish of local governments to develop a model of natural resource development that is economically, socio-culturally and ecologically beneficial. This is based on the potential for ecotourism development which is entirely based on nature and culture, so that ecotourism is accordance with tourism development planning in Konawe Islands Regency.

Third, the ecotourism development potential is also supported by promising business opportunities. The location of Konawe Islands Regency which can be reached in about 2-3 hours by boat from the capital of Southeast Sulawesi Province (Azis, Asrul, \& Risman, 2016). It can be an advantage because it is easier to access by tourists coming through the provincial capital (Sulaksono, 2017). On the other hand, the rapid growth of world ecotourism with an average of 10 percent per year (Nugroho, Negara, \& Yuniar, 2018) can be an indicator that ecotourism is very attractive to the market and deserved to be developed.

Several tourism sites in Konawe Islands Regency have been scientifically identified, for example, archeological studies of burial caves (Maskuri, 2017). In the same year, a study was also conducted on the Design and Implementation of the Tourism Potential Geographical Information System in Konawe Islands Regency (Sulaksono, 2017). This study results in geographical information about a number of tourist attraction locations in Konawe Islands, but does not display detailed information about the attractive value of a tourist attraction as will be stated in this study. There is also research on tourism objects Kampa, Tumburano, and Watuntinapi (Mukhayar et al., 2019). The research focused on the variable attraction, amenities, and accessibility of each attraction, as well as offering scientific design with AHP analysis tools for the attraction development. This research extended to other attractions, namely Sawea beach and Lanuku Waterfall, and offers a strategic activities program generated through SWOT analysis and litmus tests. Furthermore, to support the object tourism development that is integrated with the development of other resources information from the research results about Land Planning for Industrial Plant Development in
Wawonii District, Konawe Islands District (Syaf, Hemon, \& Hakim, 2019)

This research was conducted as an actualization of the local government efforts in implementing tourism development. Therefore, the research aims were to provide data and information about of the potential of natural resources and cultural communities to be used as ecotourism objects, and analyzing local community perceptions of the ecotourism businesses development. The research also aims to determine a strategic plan for ecotourism business development. The strategic must be consistent with the development policies of other sectors within the Konawe Islands Regency government frame.

\section{Research Methods}

This research was conducted in Konawe Islands Regency, in Southeast Sulawesi Province, Indonesia. Geographically, the Konawe Islands Regency lies transversely from North to South between $03^{\circ} 68$ 'and $04^{\circ} 16^{\prime}$ South latitude, stretching from west to east between $122^{\circ} 56^{\prime}$ and $123^{\circ} 16^{\prime}$ east longitude. South Konawe Regency is bordered by the Banda Sea to the north and east, and is bordered by the Wawonii Strait to the south and west. The area of Konawe Islands Regency is $867.58 \mathrm{~km}^{2}$ with a 33,680 population (BPS, 2019).

This research was conducted in AprilOctober 2019.The research study used quantitative methods with data that were collection from observations, interviews, FGD, and literature studies. Observations were held on 8 coastal attractions and 6 terrestrial attractions (rivers and waterfalls). From all of these attractions, then 2 attractions each were taken as samples, namely 2 beach attractions (Kampa beach and Sawea beach) and 2 terrestrial attractions (Tumburano waterfall and Lanuku waterfall). Sampling was purposively made with consideration character representation of the coastal and terrestrial attractions, as well as considering the attraction fame aspect in the Konawe Islands community. Field observations for an inventory of interesting physical attractions at tourist sites that become the study sample including an inventory of the number and types of flora. Inventory was done by taking a sample location using a plot with a size of $20 \mathrm{~m} \times 20 \mathrm{~m}$ through the track system. The inventory results would showed 
the quality of flora diversity that is determined by Fandeli criteria (Fandeli, 2000) as follows:

Tabel 1. Quality Criteria of Flora Diversity

\begin{tabular}{cll}
\hline Scale & \multicolumn{1}{c}{ Number of Types } & Meaning \\
\hline 1 & There are $<5$ types of plants & Bad \\
2 & $\begin{array}{l}\text { There are } 6-10 \text { types of } \\
\text { plants } \\
\text { There are } 11-20 \text { types of } \\
\text { Bad } \\
\text { plants } \\
\text { There are }>20 \text { types of } \\
\text { plants }\end{array}$ \\
\hline
\end{tabular}

Observations were also made to determine the fauna potential through the renaissance survey. During the exploration, observations were made directly or indirectly through footprints, dirt, sound, or asking field officers and the surrounding community. The quality of fauna diversity was determined by Fandeli criteria (Fandeli, 2000) as follows:

Table 2. Quality Criteria of Fauna Diversity

\begin{tabular}{clll}
\hline Scale & \multicolumn{1}{c}{ Number of Types } & Meaning \\
\hline 1 & $\begin{array}{l}\text { There are 1-2 types of animal } \\
2\end{array}$ & $\begin{array}{l}\text { There are } 3-5 \text { types of } \\
\text { animals }\end{array}$ \\
3 & $\begin{array}{l}\text { Rather } \\
\text { There are 6-10 types of } \\
\text { animals } \\
\text { There are 11-15 types of } \\
\text { animals } \\
\text { There are }>15 \text { types of } \\
\text { animals }\end{array}$ \\
\end{tabular}

In this study, interviews were conducted in two forms, as follows:

a. Interviews with 70 respondents using perspective questionnaire. Respondents were chosen purposively based on their proportional representation of village government, community leaders, actors and visitors to attractions tourism. Respondent as sample was determined with simple random sampling from 1.406 populations. The population is community living in 4 villages namely Lansilowo village (341 peoples), Wawobilli village (158 peoples), Sawaea village (464 peoples) and Wawouso village (443 peoples). Population in each village was taken 5 percent as a sample so that the total sample in this study was 141 people. This interview activity aimed to collecting information about community perceptions or responses in the attraction development.

b. Interviews of 21 respondents as a study sample using the Litmus test questionnaire. The sample was determined purposively from 59 populations consisting of 28 heads of Regional Apparatus Organizations (Government/Executive Agency), 20 leaders/members of the Regional People's Representative Assembly (Legislative Agency), 2 leaders of non-governmental organizations (NGO), 4 leaders of traditional institutions (syara)/community leaders, and 6 people managing the tourist attraction. The element population from the Executive and Legislative Agency took 5 people as a sample by considering the close relationship between the development of attractions with their roles, tasks, and responsibilities. The element population from NGO leaders, syara/community leaders and managers of attractions were taken entirely with the consideration that the amount was small while needed a lot of information from this population element.

Focus Group Discussions were done by gathering the community around a tourist attraction. FGD was held once in each place ecotourism with the number of participant present varies between 1524 people. FGD participants were invited by the researchers and determined purposively that were representing and know about the study problem, with the criteria such as live around the location of the tourist attraction, and have livelihoods related to the development of attractions. Informant elements consisted of local government, community leaders, actors, and visitors to attractions. The FGD's purposed to obtain data and information on (1) problems faced by the community in developing tourist objects; (2) solutions that have been made by the community to overcome problems; (3) expectations (vision and mission) of the community in developing tourist objects. Data and information on the results of the FGD were used in SWOT analysis and the determination of priority strategies in the tourism attraction development

The collected data was sorted, tabulated and analyzed quantitatively and qualitatively. Quantitative analysis was used to determine the importance/significance of attractions. This analysis

Available online at HABITAT website: http://www.habitat.ub.ac.id

ISSN: 0853-5167 (p); 2338-2007 (e) 
was intended to recognize the attractions importance based on a number of parameters. Quantitative analysis was also used on the measurement results of flora and fauna diversity criteria. Qualitative analysis used to understand the perceptions of local communities and formulate policy directions or strategic plans for developing the ecotourism businesses potential. The words of the community accordance the interview result analyzed by interpretation descriptively. Meanwhile, to arrange developing strategies for the ecotourism businesses potential are used SWOT (Strength, Weakness, Opportunity, and Threat) analysis method and litmus test.
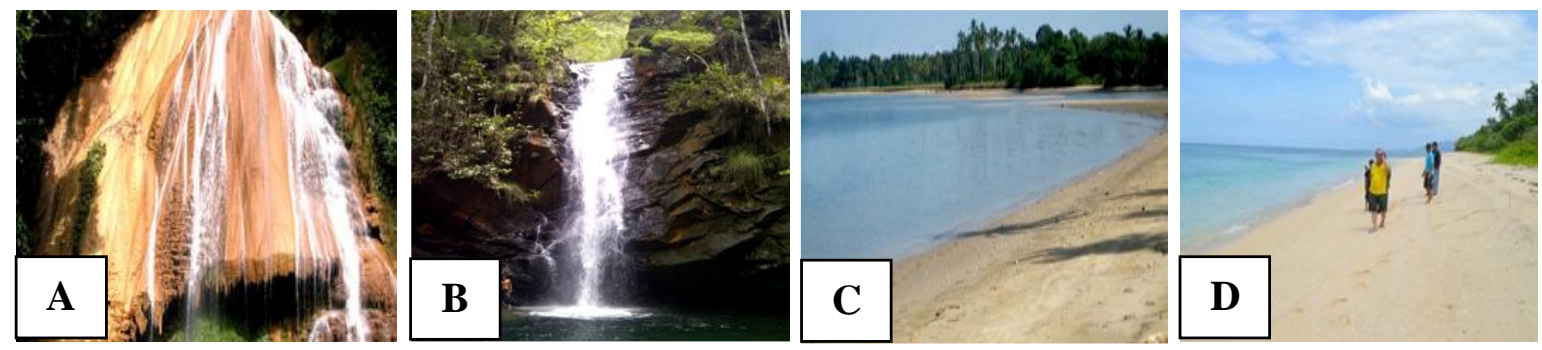

Picture 1. Natural panorama of (A) Tumburano waterfall; (B) Lanuku waterfall;

(C) Sawaea beach; and (D) Kampa beach

Tumburano waterfall has a uniqueness that rarely found in other areas, namely a very beautiful natural panorama and cliff walls through which the water has a distinctive shape with brown color that can sparkle when sunlight exposed. The waterfall area around condition still very natural and this location quite far from residential areas in the wilderness middle forest. This is very support to be used as an ecotourism object, because as it is known that most of the ecotourism objects sell the authenticity and uniqueness of the tourist attraction and far from the touch of human hands. Lanuku waterfall has a green natural panorama and is still very natural. The tourist attraction uniqueness is almost the same as the Tumburano waterfall, the difference is the relief shape and types different of watershed wall. At the Lanuku waterfall, cliff walls are still visible clearly in the form of large rocks that are blackish brown. The environment around condition seems to be care maintained, because there is no visible cutting of the trees around it. The spatial planning in the Lanuku waterfall is still possible development of adequate objects and

\section{Results and Discussion}

\subsection{Ecotourism Potentials in Konawe Islands Regency}

\subsubsection{Natural Potentials}

Based on natural conditions, attractions of ecotourism potential in Konawe Islands Regency consist of 4 (four) attractions, namely Tumburano waterfall; Lanuku waterfall; Sawaea beach; and Kampa beach. Natural panorama of the four tourist sites can be seen in the following picture: facilities without damaged of waterfalls ecosystems around.

The natural panorama of waterfall tourism is ecotourism special attraction. Tourist attraction in the Tumburano waterfall and Lanuku waterfall ecotourism area namely sound of the flowing waterfall, the flora and fauna diversity, the water and air freshness. In some areas, the panorama of waterfall tourism can be developed as a location adventure tourism (Pandey \& Pandey, 2017), natural activities or sport such as rafting, river fringing (Adi \& Danardani, 2020), outbound tours, campsites (Cholis, Hakim, Pangestuti, \& Events, 2019) and research (Klau, Affandi, \& Nugroho, 2019). The development of Tumburano waterfall and Lanuku waterfalls can use these features as tourist attraction objects.

Sawaea beach has the potential to be used as an international tourist attraction. This beach has a panoramic view of exotic sand. Sawarna Beach is maintained with its authenticity and beauty of its environment which seen in many mangrove and coconut trees that grow green and lush. The local community is also takes care for the coastal 
environment because there are no mangrove cutting activities to meet the community's wood needs. This coastal beach looks clean from rubbish both from the mainland and from the sea. Kampa beach offers a panoramic view of the white sand beauty and stunning underwater scenery. As same as Sawae beach, Kampa beach also offers the charm of crashing waves light blue hue sea. In some places, Kampa coastal ocean has coral reefs with the rich biodiversity (Mukhayar et al., 2019).

Sawaea and Kampa beach tourism objects can be developed by highlighting the beach beauty features such as white sand, panoramic view of coastal vegetation (coconut and mangrove) and the sea biodiversity. Moreover that, of all the tourism forms, visiting a beach is one of the most popular (Dodds \& Holmes, 2019), and the earliest modern forms of tourism (Picken, 2017). Thus, the development of coastal tourism has a very good market opportunity. The development of Kampa beach and Sawea beach tourism can follow some patterns of the tourist objects development namely Kuta beach tourism in Bali, Indonesia (PickelChevalier, 2018) and tourism policy development in small island (Stratigea \& Katsoni, 2015). However, the policy internalizing process of tourism development areas must still pay attention to the authenticity and uniqueness of each tourist attraction.

\subsubsection{Flora and Fauna Potentials}

The potential of flora around a tourist attraction needs to be known because it is one of the important elements that ecotourism appeal. The diversity of flora species is known through identification process by direct observation and interviews with visitors and the community around of the attraction object. The identification and inventory flora results showed that in the determined plots there were 17 types of flora. The 17 types of flora there are food plant namely paddy (Oryza sativa). Other types of flora such as fruit plants namely coconut (Cocos nucifera), guava (Eugenia $\mathrm{sp}$ ), mango (Mangifera indica), kedondong (Lonea coromande lica), Ccashew (Anacardium accidentale), and jackfruit (Artacarpus heterophyllus). There are also types of spices such as nutmeg (Myristica fragrans houut), and pepper (Piper nigrum). Apart from that, the types of flora in this place are dominated by trees and grass namely mangrove (Rhizopora alba), ketapang (Terminalia catappa), banyan (Ficus benjamina), balande tree, nypah (nypa fruticans), melinjo (Gnetum gneon), and ferns (Blechnum orientale).

Appropriate the flora diversity at attractions as mentioned above, it can be said that the flora potential is very good. The number and type higher of an area showed that the better of diversity quality (Fandeli, 2000). Fandeli also stated that the flora potential with 11-20 numbers of species has as 3 scale of value which has a pretty good meaning for eco-tourism assets. Related to the potential of vegetation, especially mangroves, based on the results of surveys and mapping in the coastal and marine areas conducted by Hasanuddin University in 2014, showed that forest cover, mangroves and sea grass in Konawe Islands Regency were still very good at over $80 \%$. It will give a high potential value. The species diversity and habitat aesthetics are an attraction while contribute to the objects development as ecotourism destinations.

In addition to identifying the flora diversity, flora and fauna species are also identified. Interactions can occur between inhabit types of flora and fauna. The location around the object is a suitable habitat for certain animal species. The results of identification and inventory fauna diversity that attraction in the location showed that Table 3:

Table 3. Quality Criteria of Fauna Diversity

\begin{tabular}{lll}
\hline \multicolumn{1}{c}{ Name } & \multicolumn{1}{c}{ Latin Name } & Description \\
\hline Mermaids & Dugong dugon & Easy to find \\
Snakes & Boiga dendrophila & Rare \\
Bath & Pteropus vampirus & Easy to find \\
Kus-kus & Phalanger orientalis & Many \\
Monitor & Varanus salvator & Many \\
lizards & & \\
Chameleons & Colotus jubatus & Many \\
Lizards & Mabouya & Many \\
Cui birds & Antreptes & Easy to find \\
& malacecsis & \\
Parrots & Eos borneo & Rare \\
Sea eagles & Haliaetus & Rare \\
Storks & leocogaster & \\
Wild boar & Ciconiidae & Easy to find \\
Types of fish & Sus scrofa & Many \\
Types & & Many \\
Molusca & & Many \\
\hline
\end{tabular}

Source: Primary data, 2019

Available online at HABITAT website: http://www.habitat.ub.ac.id

ISSN: 0853-5167 (p); 2338-2007 (e) 
From these data, it is known that the fauna potential at Konawe Islands Regency tourist attraction sites is quite diverse. By referring Fandeli criteria, the fauna diversity of these objects has a good diversity quality with 4 value scale, so it can be used as a support for area ecotourism.

\subsubsection{Konawe Islands Community Perception of Ecotourism Development}

Community perception is the community view based on their thinking ways, knowledge, and experience. This perception based on facts, hopes and desires/needs. Analysis of community perceptions in this study considered necessary because of the desire to develop community-based ecotourism. It is context that the perceptions, expectations and needs of the community are analyzed because the development strategy is formulated from the community, by the community and for the community. So, in this study inquired community participation to reveal their thinking, suggestion, and the possibility of various problems that may be faced in the attractions development. The community needs to be involved in the area management and development because they are directly related to the tourist attraction activities. The most important thing fosters a sense of belonging to natural tourism objects in them around, so that their utilization can be sustainable and community's life has more welfare level optimally. The interviews results regarding the community perception using questionnaires to 70 respondents can be seen in the following table:

Table 4. Ecotourism Community Perception and Development Expected Forms

\begin{tabular}{|c|c|c|c|c|c|c|}
\hline \multirow[b]{2}{*}{ Criteria } & \multirow[b]{2}{*}{ Parameters } & \multicolumn{4}{|c|}{$\begin{array}{r}\text { Attractions Location } \\
\end{array}$} & \multirow[b]{2}{*}{$\begin{array}{c}\text { Average } \\
\text { Percentage }\end{array}$} \\
\hline & & $\begin{array}{c}\text { Tumburano } \\
\text { waterfall }\end{array}$ & $\begin{array}{c}\text { Lanuku } \\
\text { waterfall }\end{array}$ & $\begin{array}{l}\text { Sawae } \\
\text { beach }\end{array}$ & $\begin{array}{c}\text { Kampa } \\
\text { beach }\end{array}$ & \\
\hline Agree with & A. Agree & A: 85 & $\mathrm{~A}: 75$ & $\mathrm{~A}: 85$ & A:90 & 84 \\
\hline Ecotourism & B. No Agree & B: 15 & $\mathrm{~B}: 25$ & $\mathrm{~B}: 15$ & $\mathrm{~B}: 10$ & 16 \\
\hline Development & A: For knowledge & A: 5 & A: 0 & A: 10 & A: 5 & 3 \\
\hline Expected & B: Additional facilities & B: 75 & B: 80 & B: 60 & B: 60 & 69 \\
\hline Form & C: Additional shops & $C: 25$ & C: 20 & $C: 30$ & $\mathrm{C}: 35$ & 28 \\
\hline
\end{tabular}

Source: Primary data, 2019

Based on Table 4 above there are $84 \%$ of the total 70 respondents spread across four tourist sites agree to the ecotourism development. This shows the local community appreciation to build tourism objects that are feasible and sustainable without damaging their nature. Local people want nature not to be damaged because their main livelihood is based on nature, namely farming and fishing, so that good natural conditions will greatly affect their life. The natural tourism community around the area is often a traditional farm. The amount ranges from $70 \%$ or more and they lives depend on agricultural land and sea products. The pattern of land management is used mixed farming system. Based on interviews from the local community it is known that the income they earn is not enough to be able to meet the needs of life for the whole family adequately. Therefore, they really expect other business forms as side job that can increase their income. The moment asked responses to attractions development, they are very enthusiastic, most agreements expressed and ready to support.
The community offers a form of tourism development that is managed in a participatory manner. The community can participate in tourism activities as managers or offer services as tour operators and guides. People also hope to get additional income by selling or trading, and making simple accommodation facilities such as homestays. Participatory tourism management provides opportunities for improving community welfare (Moghavvemi, 2017). People know that tourism can provide lucrative alternative employment opportunities. However, they do not know how to take advantage of these opportunities because they do not have the knowledge and skills. The community hopes to get training to increase their capacity so that they can become the main actors of tourism in their region.

\subsubsection{Ecotourism Development Strategies in Konawe Islands Regency}

Ecotourism development strategies in this study were analyzed using SWOT (Strength, Weakness, Opportunities, and Threat) analysis. The 
analysis begins by assessing the internal environment as a factor of strengths and weaknesses. Assessing of the external environment to identify opportunities and challenges in ecotourism development. The assessment results number internal and external environmental factors are then analyzed using the SWOT matrix as shown in the following table:

Table 5. SWOT Matrix Ecotourism Development in Konawe Islands Regency

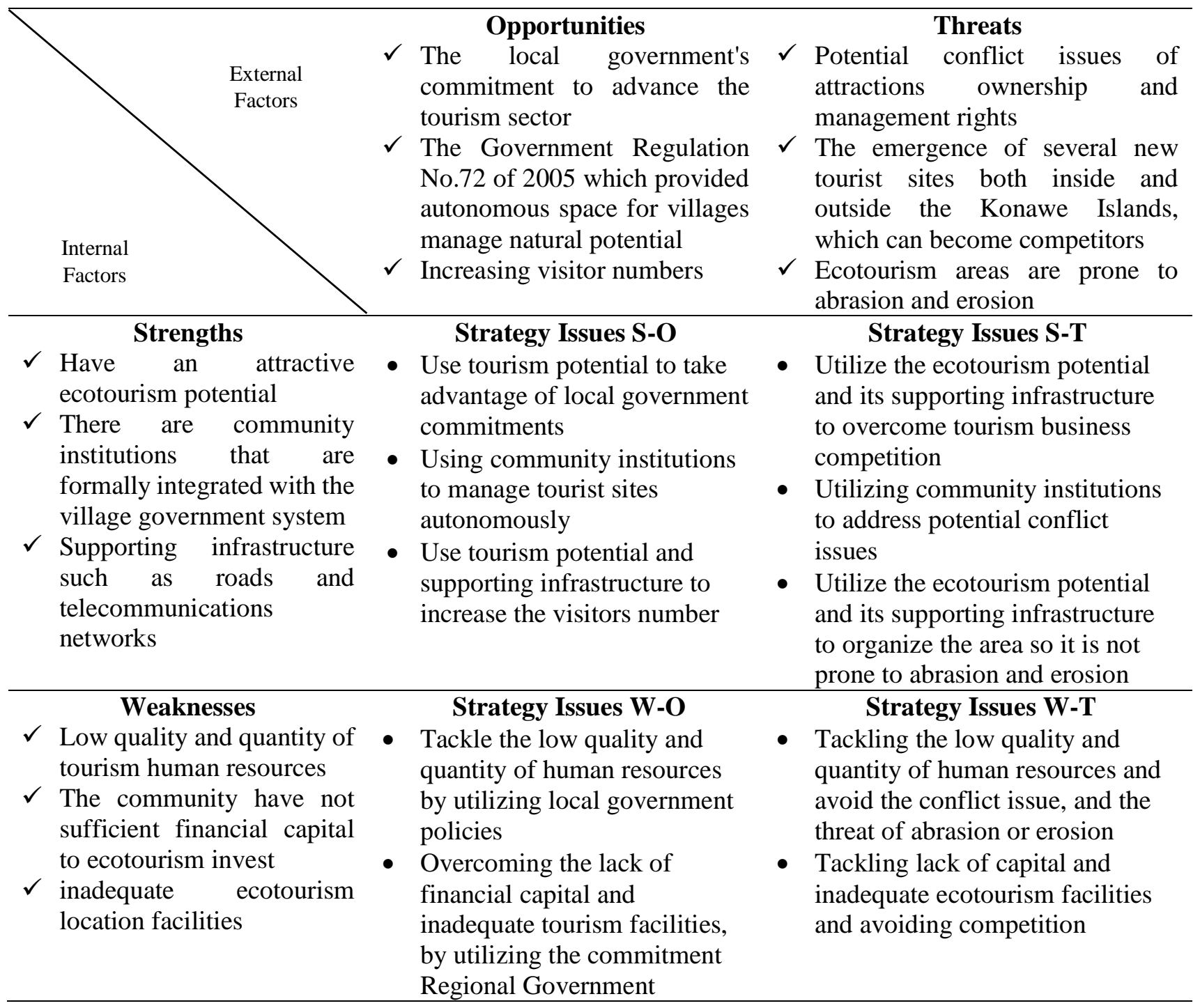

The internal and external environment assessment in the SWOT matrix as shown in table 5 results 10 strategic issues divided into strategic SO (Strengths-Opportunities), ST (Strengths-Threat), WO (Weakness-Opportunities) and WT (WeaknessThreat). The S-O strategy is formulated with a strategy that uses Strengths and utilizes Opportunities. The S-T strategy has the formula to use strengths and to overcome weaknesses. The W$\mathrm{O}$ strategy has a formula which is to overcome weaknesses by utilizing opportunities, while the $\mathrm{W}$ -
T strategy is formulated by overcoming weaknesses while avoiding challenges. The 10 strategic issues are:

a. Use tourism potential to take advantage of local government commitments;

b. Using community institutions to manage tourist sites autonomously;

c. Use tourism potential and supporting infrastructure to increase the visitors number; 
d. Utilize the ecotourism potential and its supporting infrastructure to overcome tourism business competition;

e. Utilizing community institutions to address potential conflict issues;

f. Utilize the ecotourism potential and its supporting infrastructure to organize the area so it is not prone to abrasion and erosion;

g. Tackle the low quality and quantity of human resources by utilizing local government policies;

h. Overcoming the lack of financial capital and inadequate tourism facilities, by utilizing the commitment regional government; i. Tackling the low quality and quantity of human resources and avoid the conflict issue, and the threat of abrasion or erosion; and

j. Tackling lack of capital and inadequate ecotourism facilities and avoiding competition.

The 10 strategic issues by the matrix SWOT then analysed using a Litmus test to determine Strategic (S) and Very Strategic (VS) issues. Very strategic issues are the most priority issues to be implemented in ecotourism development. The recapitulation of litmus test results presented in the table below:

Table 6. Recapitulation Result of Litmus Test

\begin{tabular}{|c|c|c|c|c|c|c|c|c|c|c|c|c|c|c|c|c|c|}
\hline \multirow{2}{*}{ No } & \multirow{2}{*}{ Issue } & \multicolumn{13}{|c|}{ Score Questions For Each Issue } & \multirow{2}{*}{$\begin{array}{l}\text { Total } \\
\text { Score }\end{array}$} & \multirow{2}{*}{$\begin{array}{c}\text { Average } \\
\text { Score }\end{array}$} & \multirow{2}{*}{$\begin{array}{c}\text { Strategic } \\
\text { Level }\end{array}$} \\
\hline & & 1 & 2 & 3 & 4 & 5 & 6 & 7 & 8 & 9 & 10 & 11 & 12 & 13 & & & \\
\hline & 1 & 1 & 3 & 1 & 1 & 1 & 1 & 3 & 3 & 3 & 3 & 2 & 2 & 1 & 25 & 1,92 & $\mathbf{S}$ \\
\hline & 2 & 1 & 3 & 1 & 1 & 1 & 1 & 1 & 1 & 3 & 3 & 3 & 2 & 2 & 23 & 1,77 & $\mathbf{S}$ \\
\hline & 3 & 1 & 3 & 3 & 3 & 1 & 1 & 3 & 3 & 3 & 3 & 3 & 3 & 1 & 31 & 2,38 & VS \\
\hline & 4 & 1 & 3 & 1 & 1 & 1 & 3 & 3 & 3 & 3 & 3 & 1 & 3 & 3 & 29 & 2,23 & $\mathbf{S}$ \\
\hline & 5 & 1 & 3 & 2 & 3 & 3 & 1 & 3 & 3 & 2 & 3 & 1 & 2 & 1 & 28 & 2,15 & $\mathbf{S}$ \\
\hline & 6 & 1 & 3 & 1 & 3 & 1 & 3 & 1 & 1 & 3 & 3 & 1 & 2 & 3 & 26 & 2,00 & $\mathbf{S}$ \\
\hline & 7 & 1 & 3 & 2 & 3 & 3 & 1 & 3 & 3 & 3 & 3 & 3 & 2 & 3 & 33 & 2,54 & VS \\
\hline & 8 & 1 & 3 & 3 & 3 & 2 & 3 & 3 & 3 & 3 & 3 & 3 & 3 & 1 & 37 & 2,85 & VS \\
\hline & 9 & 1 & 3 & 2 & 3 & 3 & 3 & 1 & 1 & 2 & 3 & 2 & 3 & 2 & 29 & 2,23 & $\mathbf{S}$ \\
\hline & 10 & 1 & 3 & 3 & 3 & 3 & 3 & 3 & 3 & 3 & 3 & 3 & 3 & 1 & 38 & 2,92 & VS \\
\hline
\end{tabular}

Source: Primary data, 2019

Notes: $S=$ Strategic; VS = Very Strategic

Table 6 shows that there are 5 very strategic (VS) issues become priority issues and need to be immediately realized in the ecotourism development, namely:

a. Use tourism potential and supporting infrastructure to increase the visitors number;

b. Tackle the low quality and quantity of human resources by utilizing local government policies;

c. Overcoming the lack of financial capital and inadequate tourism facilities, by utilizing the commitment regional government; and

d. Tackling lack of capital and inadequate ecotourism facilities and avoiding competition.

The four 'very strategic (VS)' problems will be addressed through a strategic planning mechanism. This plan aims to describe in detail the strategic actions to address these issues. So, the issue is not just an issue, but there is an effort to realize it. Realization efforts formulated in the form of ecotourism development strategy plans. The strategic plan is formulated by considering two things taking into account (1) the availability of implementation resources; and (2) the convenience in implementing strategies to achieve goals. According the analysis, there are 6 strategic program plans on ecotourism development in Konawe Islands regency, namely:

a. Increasing knowledge and skills of the tourism community;

b. Increasing the availability of financial capital for ecotourism businesses;

c. Development of ecotourism infrastructure facilities;

d. Promotion of ecotourism objects;

e. The stipulation of rules about management of attractions; and 
f. Deal with potential conflict issues and abrasion or erosion.

The six strategic program plans need to be implemented simultaneously and integrated into the work plan of local governments or other development stakeholders. Multi-party collaboration is absolutely necessary to accelerate the ecotourism development process. The multiparty collaboration system is needed because there are some community weaknesses that can be overcome by taking advantage of opportunities from other parties. The community power utilize needs respond from the development stakeholders namely government, nongovernment institution, private institution, education institution and others. Likewise, to overcome weaknesses and avoid threat needs a number of strengths and opportunities from multi stakeholder

\section{Conclusions}

The results of research through observation, exploration and inventory using track sampling system shows that Konawe Islands Regency has potential ecotourism object in coastal-sea panoramas (Sawaea beach and Kampa beach), and in the mainland with waterfalls panoramas (Tumburano waterfalls and Lanuku waterfalls). The results of importance/significance measurements indicate that the flora potential have scale value of 3 (moderate), the fauna potential have scale of value of 4 (good) and the potential criteria "B", which indicates that the tourist attraction has a potential quality to be developed as ecotourism. Local people's perception is very positive because they believe there are economic, socio-cultural and ecological benefits from ecotourism development. The results of the SWOT analysis with the Litmus test found some main strategies in form program plans such as increasing the knowledge and skills tourism community, increasing the availability of capital financial for ecotourism businesses and development of ecotourism infrastructure facilities. Besides that, the main strategies from SWOT analysis result are promotion of ecotourism objects, the stipulation of rules about management of attractions; and deal with potential conflict issues and abrasion or erosion.

\section{Acknowledgment}

This research was funded by the Regional Government of Konawe Islands Regency, Fiscal Year 2018. Data collect in the field with the exploration method was assisted by Profession Work Lecturers Program and community institutions (syara).

\section{References}

Adi, I. P. P., \& Danardani, W. (2020). SportEcotourism Development in Ambengan Village, Sukasada District, Buleleng Regency. Paper presented at the 3rd International Conference on Innovative Research Across Disciplines (ICIRAD 2019).

Azis, R., Asrul, A., \& Risman, R. (2016). Mode Choice for Sea Transportation in Archipelagic Region: The Case of KendariKonawe Route in South East Sulawesi Province. Journal of Regional City Planning, 27(2), 151-172.

Blamey, R. K. (2001). Principles of ecotourism. Journal The encyclopedia of ecotourism, 2001, 5-22.

BPS. (2019). Kabupaten Konawe Islands dalam Angka, Konawe Islands Regency in Figures. In B. P. S. K. Konawe (Ed.), (Vol. 74120.1803). Konawe BPS Kabupaten Konawe.

Carrier, J. G., \& Macleod, D. V. (2005). Bursting the bubble: The socio-cultural context of ecotourism. Journal of the Royal Anthropological Institute, 11(2), 315-334.

Chiu, Y.-T. H., Lee, W.-I., \& Chen, T.-H. (2014). Environmentally responsible behavior in ecotourism: Antecedents and implications. Journal Tourism management, 40, 321-329.

Cholis, A. F., Hakim, L., Pangestuti, E., \& Events. (2019). Sharia Tourism Development Strategy In Natural Recreation Sites of Batu City, East Java. International Journal of Applied Sciences in Tourism, 3(1), 24-37.

Dodds, R., \& Holmes, M. R. (2019). Beach tourists; what factors satisfy them and drive them to return. Journal Ocean coastal management, $168,158-166$. 
Fandeli, C. (2000). Pengusahaan ekowisata. Yogyakarta: Diterbitkan atas kerjasama Fakultas Kehutanan UGM [dengan] Pustaka Pelajar.

Fennell, D. A. (2020). Ecotourism: Routledge.

Klau, N. P., Affandi, A., \& Nugroho, I. (2019). The Role of Social Capital in the Development of Mauhalek Waterfall Ecotourism in Belu District, East Nusa Tenggara Province. Journal of Indonesian Tourism Development Studies, 7(1), 1.

Maskuri, M. (2017). Sebaran Gua Penguburan di Kabupaten Konawe Islands Propinsi Sulawesi Tenggara. Jurnal Penelitian Arkeologi, 1(2), 46-61.

Moghavvemi, S. W., Kyle M.; Paramanathan, Tanuosha; Musa, Ghazali; Hamzah, Amran. (2017). The effect of residents' personality, emotional solidarity, and community commitment on support for tourism development. Journal Tourism management, 63, 242-254.

Mukhayar, M., Pasolon, Y. B., \& Jaya, L. M. G. (2019). Daya Saing Destinasi Wisata Kampa, Tumburano, dan Watuntinapi Berbasis Spasial di Kabupaten Konawe Islands. Jurnal Perencanaan Wilayah PPS UHO, 4(2).

Nugroho, I., Negara, P. D., \& Yuniar, H. R. (2018). The planning and the development of the ecotourism and tourism village in Indonesia: a policy review. Journal of SocioeconomicsDevelopment, 1(1), 43-51.

Pandey, A. P., \& Pandey, M. (2017). Potentials and problems of adventure tourism a study of Rishikesh. ACADEMICIA: An International Multidisciplinary Research Journal, 7(3), 3138.

Pickel-Chevalier, S. (2018). Tourism in Bali and the challenge of sustainable development: Cambridge Scholars Publishing.

Picken, F. (2017). Beach tourism. The Sage International Encyclopedia of Travel Tourism, 135-136.

Stratigea, A., \& Katsoni, V. (2015). A strategic policy scenario analysis framework for the sustainable tourist development of peripheral small island areas-the case of LefkadaGreece Island. Journal European Journal of Futures Research, 3(1), 5.

Sulaksono, A. G. (2017). Perencanaan dan Implementasi Sistem Informasi Gegrafis Potensi Pariwisata Kabupaten Konawe Islands Berbasis WEB. Paper presented at the Seminar Nasional Sistem Informasi (SENASIF).

Syaf, H., Hemon, T., \& Hakim, Y. (2019). Perencanaan Lahan Untuk Pengembangan Tanaman Industri di Kecamatan Wawonii Tenggara Kabupaten Konawe Islands. Physical Social Geography Research Journal, 1(1), 23-34.

Wood, M. (2002). Ecotourism: Principles, practices and policies for sustainability: UNEP. 